\title{
Analysis of Gottingen 428 Airfoil Turbine Propeller Design with CFD Method on Gravitational Water Vortex Power Plant
}

\author{
Ede Mehta Wardhana ${ }^{1}$, Agoes Santoso ${ }^{2}$, Asep Rahmat Ramdani ${ }^{3}$
}

Received: 04 February 2019 / Revised: 18 March 2019 / Accepted: 19 March 2019

\begin{abstract}
-along with technological development and the increase in human population, the electricity needs are increasing every year. However, $94 \%$ of a power plant in Indonesia still using fossil fuels that are a pollutant and non-renewable. In addition, NASA said that the earth's temperature had risen by $1^{\circ} \mathrm{C}$ since 1880 and the current carbon dioxide level was the highest in the last 650,000 years. Therefore, Indonesia needs to improve, in fact, Indonesia is one of the highest emission contributors in the world. Indonesia is not yet $100 \%$ electrified, there are still 2,519 villages without electricity. Gravitational Water Vortex Power Plant (GWVPP) is a micro hydro-power plant may answer the problem because it is easy renewable energy to be made and utilized in the NIZ (not interconnected zones) region. This study will examine the changes in the number and shape of the blade, as well as the length of the chord, to know the effect on turbine power so that it can produce higher efficiency at GWVPP. Propeller turbine with a Gottingen 428 airfoil analyzed using Computational Fluid Dynamics (CFD) method. The results show that the number of blades and the length of the chord is inversely proportional to the efficiency of the turbine, and the shape of the blade is more efficient when it's twisted.
\end{abstract}

Keywords-CFD, GWVPP, Micro Hydro, Renewable Energy, Turbine.

\section{INTRODUCTION}

$\mathrm{E}$ lectricity needs are increasing every year, but the availability of energy sources such as oil, gas, and coal is depleting. In addition, the condition of the earth faced with climate change has worsened. This encourages people to immediately switch to using renewable energy by utilizing natural resources such as solar power, wind power, water flow, geothermal energy, and biological processes. In Indonesia itself, electricity distribution is being increased so that all regions to remote areas can experience the benefits of electricity so that it can increase the productivity of local residents and the economic growth of the country. To solve all those problems, Gravitational Water Vortex Power Plant (GWVPP) can be a solution because it is easy renewable energy to be made and utilized in the NIZ area.

GWVPP is a new type of low head turbine system where basin structures are used to form vortex flow, then kinetic energy can be generated from turbine rotation [1-4]. GWVPP can be used in river flows by constructing power plants in watersheds. River water will flow through the ditch to the basin which contains a turbine and returns to the river, so that the turbine will rotating to produce kinetic energy and converted into electrical energy. Based on data from the Turbulent company from Belgium, they claim that the turbine is safe to pass by fish and can produce power of 5 to $100 \mathrm{~kW}$ depending on the flow rate of the river and the head used [5-10]. This type of plant is very suiTable for use in remote areas that have rivers, so that the area can be energy independent with a decentralized system.
Ede Mehta Wardhana. Department of Marine Engineering ITS Surabaya, 60111, Indonesia. Email: edewardhana123@gmail.com

Agoes Santoso. Department of Marine Engineering ITS Surabaya, 60111, Indonesia. Email: agoes@its.ac.id

Asep Rahmat Ramdani, Department of Marine Engineering ITS Surabaya, 60111, Indonesia. Email: aseprahmat101@ gmail.com

\section{METHOD}

In this research, turbine was designed by using CAS Software and the computational fluid dynamic (CFD) simulated by CFD Tools. The output from simulation is to know the torque and how the water flow in the basin.

\section{A. Preliminary}

According to the Ministry of Energy and Mineral Resources, $94 \%$ of power plants in Indonesia still using pollutant and non-renewable natural resources. While the reserves of fossil fuels are projected to run out in the next few decades and the condition of the earth is getting worse towards global climate change due to global warming. The need for clean renewable energy is undeniable. For renewable energy potential in Indonesia, according to the Ministry of Energy and Mineral Resources are in Table 1.

\section{B. Turbine}

Hydroelectric power plants are not separated from the turbine. Water turbines are devices for converting potential water energy into mechanical energy. This mechanical energy then converted into electrical energy by a generator.

Judging from the reaction, turbines can be divided into impulse turbines and reaction turbines. The selection of the type of turbine is strongly influenced by the head and flow rate at the plant location. In addition, efficiency and cost factors are often considered [11-20].

1) Impulse Turbine

The impulse turbine generally uses the speed of the water to move the runner and is released at atmospheric pressure. The flow of water sprayed each 
dish on the runner. Impulse turbines are generally suiTable for those with high head and low water

volume e.g. Pelton turbine (200-2000 meter; 4-15 $\left.\mathrm{m}^{3} / \mathrm{s}\right)$ and cross flow turbine $\left(<200 \mathrm{~m} ;>15 \mathrm{~m}^{3} / \mathrm{s}\right)$.

2) Reaction Turbine

The reaction turbine produces power from a combination of pressure and water movement. The runner is placed directly on the current flow. The reaction turbine is usually used for Hydroelectric Power Plant or Micro Hydro Power Plant which has a lower head and a larger flow rate than an impulse turbine e.g. Francis turbine, kinetic turbine, and propeller turbine.

Propeller turbines has been used as research objects. This turbine was chosen because it is capable of working on a low head, high flow rate, and suiTable for use on rivers. The propeller turbine generally has runners with 3 to 6 blades where the water hits all the blades constantly. The pitch of the blade can be designed to fix or adjustable.

\section{Gravitational Water Vortex Power Plant (GWVPP)}

Gravitational Water Vortex Power Plant is a type of green technology that falls in the category of the micro hydropower plant. It is currently being categorized as micro-hydropower because the maximum reported power generation had not exceeded $100 \mathrm{~kW}$. The main advantage of this power plant is the ultra-low hydraulic head requirement as well as environmentally friendly. In this plant, the water passes through a large, straight inlet,

TABLE 1.

RENEWABLE ENERGY POTENTIAL IN INDONESIA

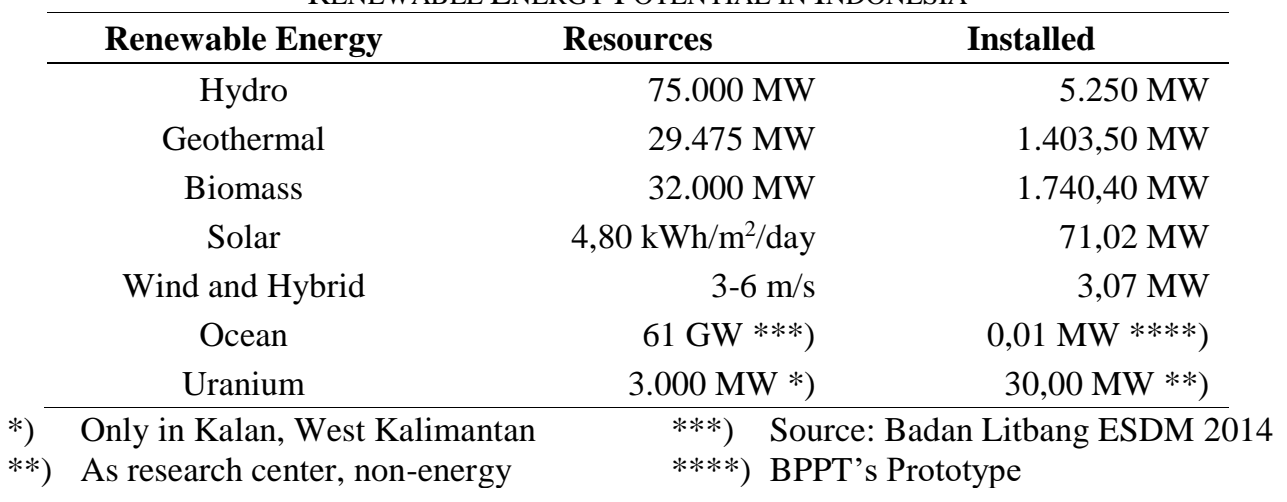

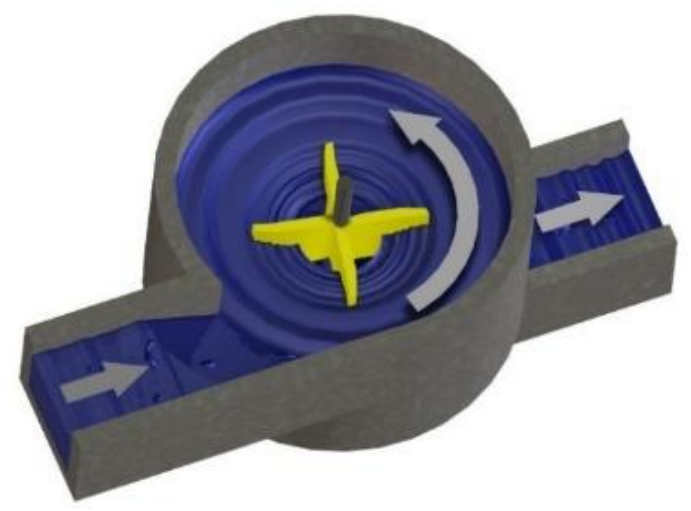

Figure 1. Gravitational water vortex power plant

TABLE 2.

PRICE/WATT COMPARISON FOR EACH POWER PLANT

\begin{tabular}{ccc}
\hline Power Plant & Capacity Factor & Price/Watt \\
\hline Hydro & 52 & $1 \$$ \\
Solar & 25 & $1 \$$ \\
Wind & 34 & $2 \$$ \\
Coal & 85 & $2 \$$ \\
Nuclear & 90 & $2,1 \$$ \\
Gas & 87 & Varies \\
GWVPP & $>95$ & $1 \$$ \\
\hline
\end{tabular}


which then passes tangentially into a round basin. The water will then form a powerful vortex, which exits the outlet at the center bottom of the shallow basin as can be seen in figure 1. Due to its ultra-low hydraulic head requirement, the plant does not work on the pressure difference but on the dynamic force generated by vortex. Hence, the development and power generation costs are very low in the GWVPP compared to other hydropower technologies.

According to the turbulent company from Belgium, they are capable of producing 3 to $20 \mathrm{MW}$ of power when combined. The design and installation are very easy and flexible with regard to the river conditions. With a decentralized system, the risk of damage that appears will decrease and the operating costs has been low. In addition, there is a monitoring system that makes it easier for us to carry out maintenance.

Based on research conducted by Anjali Mohanan M, a student of Government Engineering College, Barton Hill India. GWVPP has the highest Capacity Factor with the lowest price per watt compared to other types of plants, both with fossil fuels and renewable energy. Following is the comparison as in Table 2.

\section{Computational Fluid Dynamics (CFD)}

Computational Fluid Dynamic is a branch of fluid mechanics that uses numerical methods and algorithms to solve and analyze problems that involve the flow of fluid [10]. The principle is that space contains fluid to be calculated by divide it into several parts, this is often called a cell and the process is called meshing. The divided parts are a calculation control that has been carried out by the application or software. Later, at each calculation control point, the application has been calculated with the boundary domain and boundary conditions specified.

The results obtained at the closest control point of calculating the equations involved has been continued to the other closest control points continuously until the entire domain is fulfilled. Finally, the results obtained has been presented in the form of colors, vectors, and values that are easy to see with the range configuration taken from the largest and smallest values. In general, the CFD calculation process consists of 3 main parts:

1) Pre-processor

The stage where data is inputted starting from defining the domain and defining boundary condition. In this stage, an object has been divided by a certain number of grids or often referred to as meshing.

2) Solver

At this stage, the process of calculating input data is carried out with equations that are involved iteratively. This means that the calculation is done until the results lead to the smallest error or to reach a convergent value. The calculation is carried out thoroughly on the volume control with the discrete equation integration process.

3) Post-processing

The last stage where the results of calculations are interpreted into images, graphics and even animation with certain color patterns. Post-processors are increasingly developing with the advancement of engineering workstations that have considerable graphics and visualization capabilities.

\section{E. Equation}

There is a formula for use in this research consists of: Specific hydraulic energy

$$
\mathrm{E}=\mathrm{g} \mathrm{H}_{\mathrm{n}}
$$

Where: $\mathrm{E}=$ specific hydraulic energy $(\mathrm{J} / \mathrm{kg})$

$$
\begin{aligned}
& \mathrm{g}=\text { gravitation }\left(\mathrm{m} / \mathrm{s}^{2}\right) \\
& \mathrm{H}_{\mathrm{n}}=\text { net head }(\mathrm{m})
\end{aligned}
$$

Specific speed of propeller turbine $\mathrm{n}_{\mathrm{QE}}=2.716 / \mathrm{H}_{\mathrm{n}}{ }^{0.5}$

Where: $\mathrm{n}_{\mathrm{QE}}=$ specific speed of propeller turbine $\mathrm{H}_{\mathrm{n}}=$ net head $(\mathrm{m})$

RPS of the turbine (n)

$$
n=\frac{n_{Q E} E^{\frac{3}{4}}}{\sqrt{Q}}
$$

Where: $\mathrm{n}=$ RPS of the turbine $\mathrm{n}_{\mathrm{QE}}=$ specific speed of propeller turbine $\mathrm{E}=$ specific hydraulic energy $(\mathrm{J} / \mathrm{kg})$

$\mathrm{Q}=$ flow rate $\left(\mathrm{m}^{3} / \mathrm{s}\right)$

Outside diameter (De) and inside diameter (Di) of turbine

$$
\begin{aligned}
& D e=84.5\left(0.79+1.602 n_{Q E}\right) \frac{\sqrt{H_{n}}}{60 n} \\
& D i=\left(0.25+\frac{0.0951}{n_{Q E}}\right) D e \\
& \text { Where: } \begin{array}{l}
\mathrm{De}=\text { outide diameter }(\mathrm{m}) \\
\mathrm{Di}=\text { inside diameter }(\mathrm{m}) \\
\mathrm{n}_{\mathrm{QE}}=\text { specific speed of propeller turbine } \\
\mathrm{H}_{\mathrm{n}}=\text { net head }(\mathrm{m}) \\
\mathrm{n}=\text { RPS of turbine }
\end{array}
\end{aligned}
$$

Inlet surface area $(\mathrm{A})$

$$
A=p l
$$

Where: $A=$ inlet surface area $\left(\mathrm{m}^{2}\right)$

$\mathrm{p}=$ inlet length $(\mathrm{m})$

1 = inlet width $(\mathrm{m})$

Flow rate $(\mathrm{Q})$

$$
v=Q / A
$$

Where: $\mathrm{V}=$ water velocity $(\mathrm{m} / \mathrm{s})$

$\mathrm{Q}=$ flow rate $\left(\mathrm{m}^{3} / \mathrm{s}\right)$

A $=$ inlet surface area $\left(\mathrm{m}^{2}\right)$

Mass flow (m)

$$
m=\rho Q
$$

Where: $\mathrm{m}=$ mass flow $(\mathrm{kg} / \mathrm{s})$

$$
\begin{aligned}
& \rho=\text { density }\left(\mathrm{kg} / \mathrm{m}^{3}\right) \\
& \mathrm{Q}=\text { flow rate }\left(\mathrm{m}^{3} / \mathrm{s}\right)
\end{aligned}
$$

The potential power of the river (Pin)

$$
\text { Pin }=\rho g H Q
$$

Where: $\mathrm{P}_{\text {in }}=$ potential power of the river (watt)

$$
\begin{aligned}
\rho & =\operatorname{density}\left(\mathrm{kg} / \mathrm{m}^{3}\right) \\
\mathrm{Q} & =\text { flow rate }\left(\mathrm{m}^{3} / \mathrm{s}\right) \\
\mathrm{g} & =\operatorname{gravitation}\left(\mathrm{m} / \mathrm{s}^{2}\right) \\
\mathrm{H} & =\operatorname{Head} \text { of } \operatorname{vortex}(\mathrm{m})
\end{aligned}
$$

Torque (T)

$$
T=F R
$$

Where: $\begin{aligned} \mathrm{T} & =\text { Torque }(\mathrm{Nm}) \\ \mathrm{F} & =\text { Force }(\mathrm{N})\end{aligned}$

$\mathrm{R}=\operatorname{Radius}(\mathrm{m})$ 
Angular speed $(\omega)$

$$
\begin{aligned}
& \omega= \frac{2 \pi n}{60} \\
& v= \omega r \\
& \text { Where: } \omega \quad=\text { angular speed }(\mathrm{rad} / \mathrm{s}) \\
& \mathrm{n}=\text { rotation per minute }(\mathrm{rpm}) \\
& \mathrm{v}=\text { water velocity }(\mathrm{m} / \mathrm{s}) \\
& \mathrm{r} \quad=\text { radius }(\mathrm{m}) \\
& \text { Power of turbine (Pout) } \\
& \text { Pout }=T \omega \\
& \text { Where: } \mathrm{P}_{\text {out }}=\text { power of turbine }(\mathrm{watt}) \\
& \mathrm{T}=\text { torque }(\mathrm{Nm}) \\
& \omega=\text { angular speed }(\mathrm{rad} / \mathrm{s})
\end{aligned}
$$

Turbine efficiency $\left(\eta_{t}\right)$

$$
\eta_{t}=\frac{\text { Pout }}{\text { Pin }} 100 \%
$$

Where: $\eta_{t}=$ turbine efficiency $(\%)$

$\mathrm{P}_{\mathrm{in}}=$ potential power of the river (watt)

$\mathrm{P}_{\text {out }}=$ power of turbine (watt)

\section{RESULTS AND DISCUSSION}

\section{A. Airfoil Gottingen 428}

The airfoil selection referring to the paper application of CFD to the design of the runner of a propeller turbine for small hydroelectric power plants by Edwin Lenin, et al. The Gottingen 428 airfoil turbine propeller was recommended to be used for axial turbine.

\section{B. Gravitational Water Vortex Power Plant (GWVPP)}

The data in this research refer to data provided by Turbulent which is a Belgian Gravitational Water Vortex Power Plant Company. There are several data adjustments due to the limited information that can be provided. Some of the data is obtained from the results of other studies. The aim of this research only to obtain the turbine configuration with the highest efficiency, so that calculations are not carried out until the power generated by the generator.

The dimensions in Table 5 can be used to draw a basin by observing Figure 2 . The author does not determine the river to be analyzed, therefore the river flow is assumed by referring to Turbulent data. From the river flow rate range in Table 5, three variations has been simulated on CFD Analysis tool, which is $2.8 \mathrm{~m} 3 / \mathrm{h}, 4.2 \mathrm{~m} 3 / \mathrm{h}$, and $5.6 \mathrm{~m} 3 / \mathrm{h}$. While the head using $2 \mathrm{~m}$, taken from the minimum head value according to the ESHA (European Small Hydropower Association) in the book Guide on How to Develop a Small Hydropower Plant as in Table 6.

\section{Turbine and Basin Design}

Turbines and basin are modeled using CAD Software. Some configuration is carried out by several assumptions to get a streamlined model result.

- Angle of attack chord $0.49=29^{\circ}$

- Angle of attack chord $0.65=25^{\circ}$

- Twisted angle $\quad=40^{\circ}$

The main dimensions of the basin follow the detailed specifications provided by Turbulent. Figure 3 is the basin structure planned for this research. The model is only made in parts that have vortex, because if it starts from the river it will produce a large simulation and requires a high end computer to run the simulation. Figure 4 is the turbine model with variation as in Table 8 . The turbine and basin model need to become one model before running the simulation.

When operating, the propeller turbine will work effectively if the head and river discharge tend to be stable. Therefore, in selecting the river location to be installed by GWVPP we need to make a periodic survey or looking for data on the river flow -if available- to determine the average flow rate and head. It needs to be done so that we know if there is an extreme change in flow rate which can significantly reduce the turbine efficiency. However, it is not impossible to apply the GWVPP to the areas with extreme rainfall changes. To anticipate flow rate which varies greatly over time, a retention pool might be needed to regulate the flow of water flowing into the basin. From Table 7 we can see each turbine tolerance to the head and flow rates variations.

\section{Simulation}

1) Input geometry

Models are made in CAD Software, so the author needs to import models from CAD Software with Parasolid file formats, e.g. .xmt, .stl, .stp, .igs, etc. which the author uses igs because it is commonly used. The turbine model and basin model are made into one model, where the basin became the domain of simulation. The basin model is not the same as the model in figure 3 , because the domain requires only one layer of the boundary, so there is no thickness on the model to be simulated. The simulated model consists of a basin model that is subtracted by a turbine model using boolean functions.

2) Meshing

In the meshing stage, as can be seen in figure 5 , errors often occur due to incorrect models. Before generating meshing, the model needs to be defined as an inlet, outlet, and wall. After defining, face sizing and inflation are added to focus meshing on several cells that require higher accuracy too. Mesh used in this research is a type of unstructured mesh, where the cell shape is not structured. The number of meshing cells in this research only ranges from 450,000 to 512,000 cells.

3) Setup boundary

Problem type

Fluid

: Single phase

Analysis type

Reference pressure

: Water

Heat transfer

: Steady state

Turbulence

: 1 atm

: Thermal energy

Wall influence on flow : No slip wall

Inlet

Flow specification : Normal speed

Normal speed $\quad: 2.745 \mathrm{~m} / \mathrm{s} ; 4.118 \mathrm{~m} / \mathrm{s}$;

$5.49 \mathrm{~m} / \mathrm{s}$

Temp. specification $: 27.6{ }^{\circ} \mathrm{C}$

Outlet

Flow specification : Mass flow rate

Mass flow rate

: $2800 \mathrm{~kg} / \mathrm{s} ; 4200 \mathrm{~kg} / \mathrm{s}$; $5600 \mathrm{~kg} / \mathrm{s}$

Iteration number $\quad: 500$

Turbine material : Aluminium

Basin material : Concrete 
International Journal of Marine Engineering Innovation and Research, Vol. 3(3), Mar. 2019. 69-77 (pISSN: 2541-5972, eISSN: 2548-1479)

TABLE 3.

TURBINE CONFIGURATIONS

\begin{tabular}{cccc}
\hline Turbine Shape & Number of Blade & Chord Length & Turbine Code \\
\hline Curved & 3 & $0,49 \mathrm{~m}$ & C-3-490 \\
Curved & 3 & $0,65 \mathrm{~m}$ & C-3-650 \\
Curved & 6 & $0,49 \mathrm{~m}$ & C-6-490 \\
Curved & 6 & $0,65 \mathrm{~m}$ & C-6-650 \\
Twisted & 3 & $0,49 \mathrm{~m}$ & T-3-490 \\
Twisted & 3 & $0,65 \mathrm{~m}$ & T-3-650 \\
Twisted & 6 & $0,49 \mathrm{~m}$ & T-6-490 \\
Twisted & 6 & $0,65 \mathrm{~m}$ & T-6-650 \\
\hline
\end{tabular}

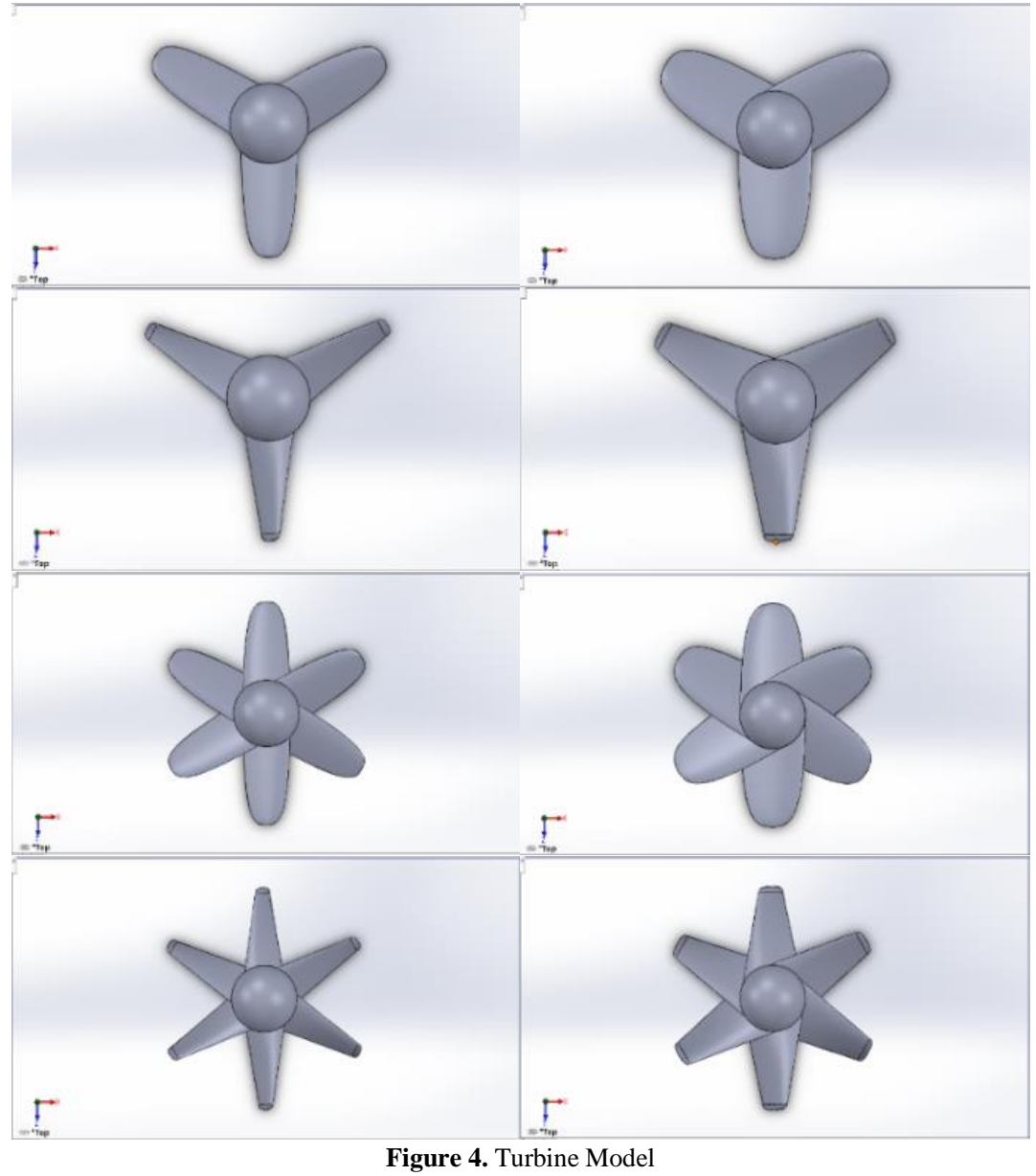

Figure 4. Turbine Model

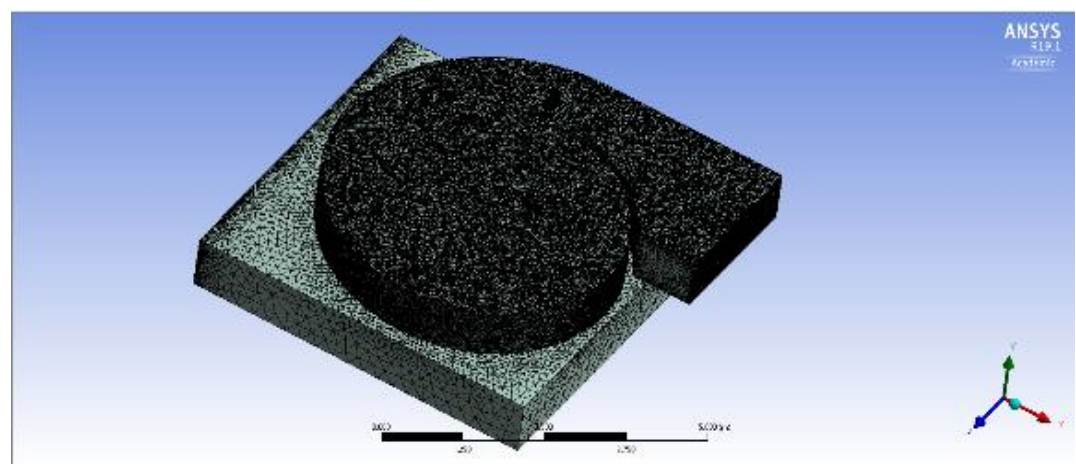

Figure 5. Meshing 


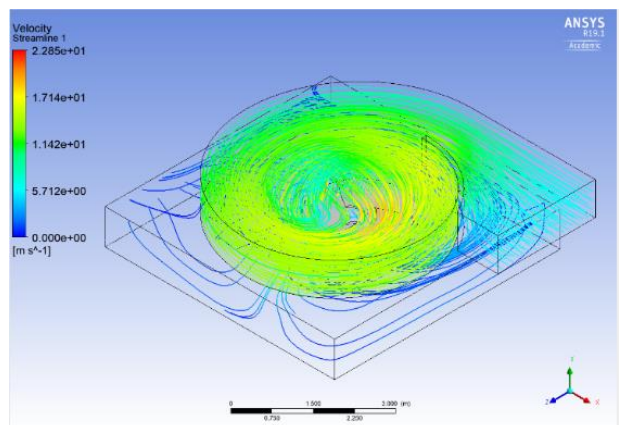

Figure 6(a). Turbine C-3-490 at speed $5.49 \mathrm{~m} / \mathrm{s}$

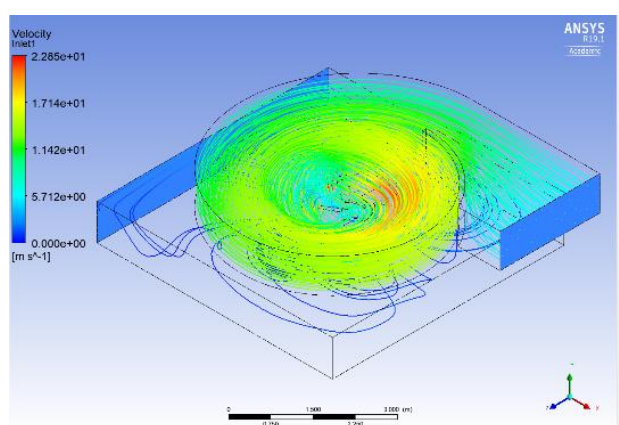

Figure 6(c). Turbine C-6-490 at speed 5.49 m/s

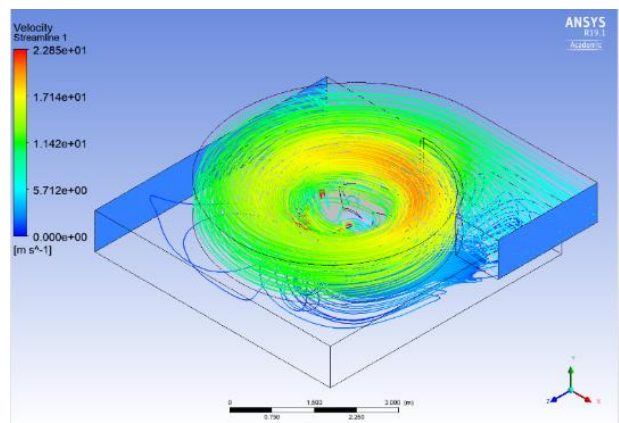

Figure 7(a). Turbine T-3-490 at speed $5.49 \mathrm{~m} / \mathrm{s}$

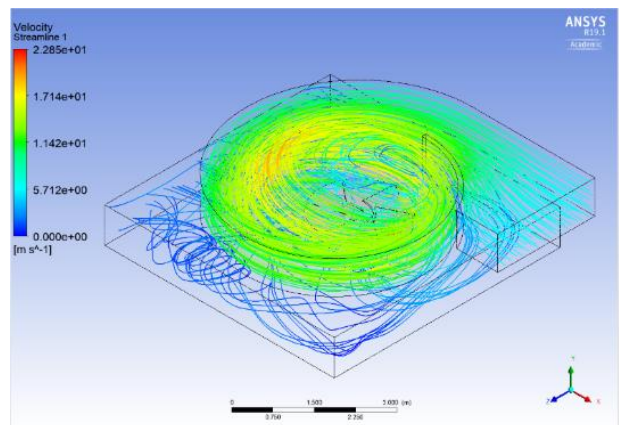

Figure 7(c). Turbine T-6-490 at speed $5.49 \mathrm{~m} / \mathrm{s}$

\section{4) Iteration}

At this stage, the process of calculating input data is carried out with equations that are involved iteratively. This means that the calculation is done until the results lead to the smallest error or to reach a convergent value. The calculation is carried out thoroughly on the volume control with the discrete equation integration process. This iteration takes a long time, ranges from 5-12 hours. The duration of iteration depends on the complexity of the model, the output to be obtained, the number of cells, and the type of accuracy used.

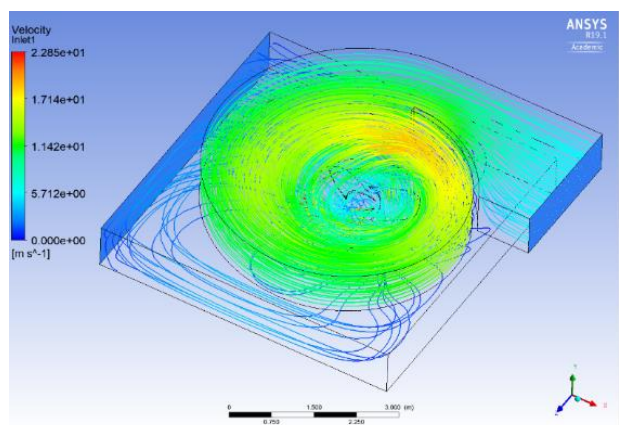

Figure 6(b). Turbine C-3-650 at speed $5.49 \mathrm{~m} / \mathrm{s}$

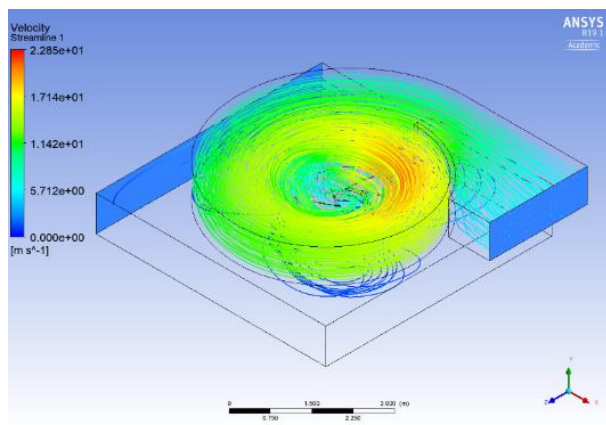

Figure 6(d). Turbine C-6-650 at speed $5.49 \mathrm{~m} / \mathrm{s}$

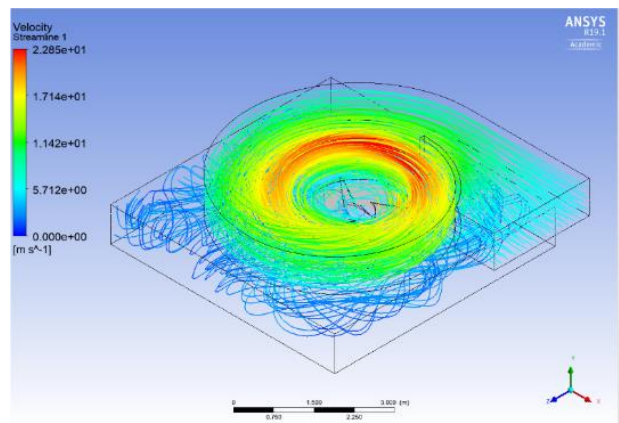

Figure 7(b). Turbine T-3-650 at speed $5.49 \mathrm{~m} / \mathrm{s}$

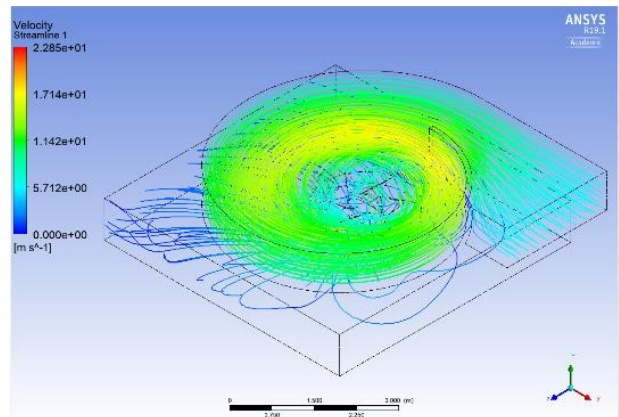

Figure 7(d). Turbinee T-6-650 at speed $5.49 \mathrm{~m} / \mathrm{s}$

5) Post processing

In the visualization of each turbine, there are five main colors, light blue, green, yellow, orange, and dark blue. On the inlet side the flow velocity has been determined which is $2.745 \mathrm{~m} / \mathrm{s}, 4.118 \mathrm{~m} / \mathrm{s}, 5.49 \mathrm{~m} / \mathrm{s}$ which is light blue, then moves towards the semicircular basin there is a narrowing of the area so that the speed increases marked in green, then forms vortex so the flow speed increases with yellow and orange. When exiting the vortex area, because there is a large increase and pushing the turbine, the flow velocity drops with a dark blue color. 
The color indicator next to the turbine is adjusted to the speed of each turbine. So, the color indication for each image has a different speed value even though it has the same color. In visualization 3 variations of speed can be seen clearly that the faster the water flows, the increase in speed when the water forms a very high vortex. This can be seen from the colors yellow and orange in the vortex.

The following visualizations can be seen in figure 6 and 7, shows that the T-3-650 turbine has orange color more intense. The orange color indicates that the velocity of the fluid is high. According to the results of previous studies, the speed is directly proportional to the efficiency of the turbine so that the T-3-650 may have the highest efficiency.

\section{6) Validation}

After getting the simulation results, inlets and outlets mass flow are compared. The mass flow value can be found in the function calculator by determining its function, mass flow, then select the location and fluid you want to find the value after that select calculate to find out the results. From the results calculated by the computer, the T-3-650 turbine simulation found that mass flow inlet $5583.2 \mathrm{~kg} / \mathrm{s}$ and mass flow outlet $5341.6 \mathrm{~kg} / \mathrm{s}$, resulting in an error $4.33 \%$.

\section{E. Result Analysis}

From the simulation results on the CFD Analysis tool, the torque data of each turbine is obtained in Table 9. Based on the data, when the number of blades is 6 with a chord length of $650 \mathrm{~mm}$, the torque produced is greater.

TABLE 4.

TORQUE DATA

\begin{tabular}{|c|c|c|c|c|c|}
\hline \multirow{2}{*}{ Blade Shape } & \multirow{2}{*}{$\mathbf{V}_{\text {river }}(\mathbf{m} / \mathbf{s})$} & \multicolumn{4}{|c|}{ Blade Number } \\
\hline & & \multicolumn{2}{|c|}{3} & \multicolumn{2}{|c|}{6} \\
\hline \multirow{3}{*}{ Curved } & 2.745 & 5455.14 & 4767.93 & 4361.99 & 4819.24 \\
\hline & 4.118 & 8398.07 & 7591.88 & 8185.89 & 7862.78 \\
\hline & 5.490 & 10668.55 & 9959.43 & 10264.54 & 10574.81 \\
\hline \multirow{3}{*}{ Twisted } & 2.745 & 5145.69 & 5749.68 & 4411.07 & 4561.18 \\
\hline & 4.118 & 7121.24 & 8568.86 & 7363.50 & 7712.84 \\
\hline & 5.490 & 10886.98 & 9748.85 & 9876.30 & 10117.06 \\
\hline \multirow{2}{*}{\multicolumn{2}{|c|}{$\begin{array}{c}\text { Torque of Turbine Table } \\
\text { (Nm) }\end{array}$}} & $490 \mathrm{~mm}$ & $650 \mathrm{~mm}$ & $490 \mathrm{~mm}$ & $650 \mathrm{~mm}$ \\
\hline & & \multicolumn{4}{|c|}{ Chord Length (mm) } \\
\hline
\end{tabular}

TABLE 5.

POWER OF TURBINE DATA

\begin{tabular}{|c|c|c|c|c|c|}
\hline \multirow{2}{*}{ Blade Shape } & \multirow{2}{*}{$\mathbf{V}_{\text {river }}(\mathbf{m} / \mathbf{s})$} & \multicolumn{4}{|c|}{ Blade Number } \\
\hline & & \multicolumn{2}{|c|}{3} & \multicolumn{2}{|c|}{6} \\
\hline \multirow{3}{*}{ Curved } & 2.745 & 14.97 & 13.09 & 11.97 & 13.23 \\
\hline & 4.118 & 34.58 & 31.26 & 33.71 & 32.38 \\
\hline & 5.490 & 58.57 & 54.68 & 56.35 & 58.06 \\
\hline \multirow{3}{*}{ Twisted } & 2.745 & 14.13 & 15.78 & 12.11 & 12.52 \\
\hline & 4.118 & 29.32 & 35.28 & 30.32 & 31.76 \\
\hline & 5.490 & 59.77 & 53.52 & 54.22 & 55.54 \\
\hline \multirow{2}{*}{\multicolumn{2}{|c|}{ Power of Turbine Table $(\mathrm{kW})$}} & $490 \mathrm{~mm}$ & $650 \mathrm{~mm}$ & $490 \mathrm{~mm}$ & $650 \mathrm{~mm}$ \\
\hline & & \multicolumn{4}{|c|}{ Chord Length (mm) } \\
\hline
\end{tabular}

TABLE 6.

EFFICIENCY DATA

\begin{tabular}{|c|c|c|c|c|c|}
\hline \multirow{2}{*}{ Blade Shape } & \multirow{2}{*}{$\mathbf{V}_{\text {river }}(\mathbf{m} / \mathbf{s})$} & \multicolumn{4}{|c|}{ Blade Number } \\
\hline & & \multicolumn{2}{|c|}{3} & \multicolumn{2}{|c|}{6} \\
\hline \multirow{3}{*}{ Curved } & 2.745 & $27.26 \%$ & $23.82 \%$ & $21.80 \%$ & $24.08 \%$ \\
\hline & 4.118 & $41.96 \%$ & $37.94 \%$ & $40.90 \%$ & $39.29 \%$ \\
\hline & 5.490 & $53.31 \%$ & $49.77 \%$ & $51.29 \%$ & $52.84 \%$ \\
\hline \multirow{3}{*}{ Twisted } & 2.745 & $25.71 \%$ & $28.73 \%$ & $22.04 \%$ & $22.79 \%$ \\
\hline & 4.118 & $35.58 \%$ & $42.82 \%$ & $36.79 \%$ & $38.54 \%$ \\
\hline & 5.490 & $54.40 \%$ & $48.71 \%$ & $49.35 \%$ & $50.55 \%$ \\
\hline \multirow{2}{*}{\multicolumn{2}{|c|}{$\begin{array}{c}\text { Efficiency of Turbine Table } \\
(\%)\end{array}$}} & $490 \mathrm{~mm}$ & $650 \mathrm{~mm}$ & $490 \mathrm{~mm}$ & $650 \mathrm{~mm}$ \\
\hline & & \multicolumn{4}{|c|}{ Chord Length (mm) } \\
\hline
\end{tabular}


This is in line with the theory because basically torque gets bigger when the weight of the object gets bigger. However, there is an anomaly at the $490 \mathrm{~mm}$ chord length, where torque is higher when the number of blades is 3 .

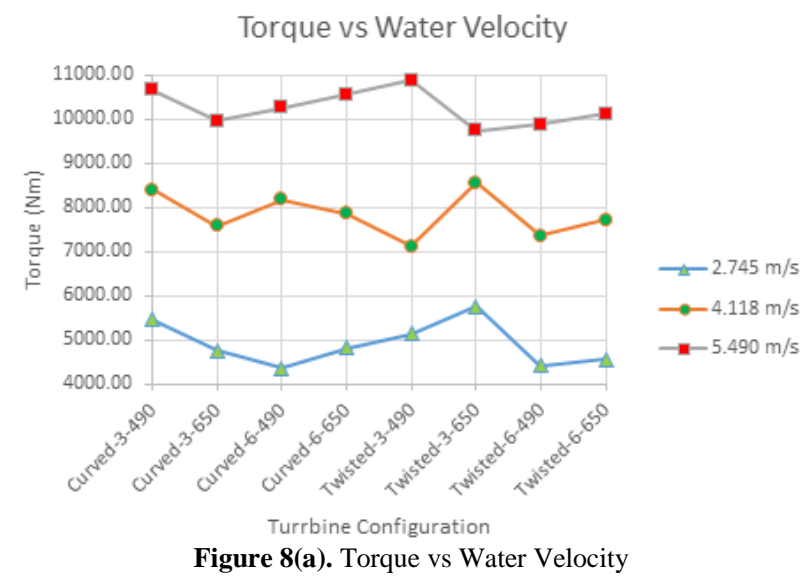

Efficiency vs Water Velocity

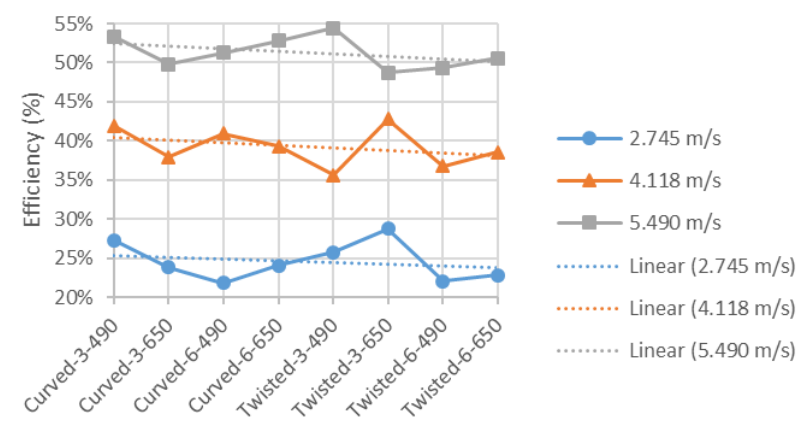

Turbine Configuration (Curved to Twisted Shaped)

Figure 9(a). Efficiency vs Water Velocity

(Comparison Between Curved and Twisted Blade)

As with the number of blades, the longer the chord will increase torque due to the greater weight of the object. This can be seen in the chord length 490 and 650 columns when the chord gets shorter the torque becomes bigger. According to the author's hypothesis, this might be due to the wider chord surface area resulting in the turbine more difficult to spin, so that the resulting torque is smaller on the longer chord.

In Table 10, it was found that the torque was slightly larger in curved form than twisted. Variations in river water speed also affect the torque that occurs in the turbine, where the faster the water flows, the greater the torque produced by the turbine. with the number of blades 6 in Table 10. However, the anomaly happens again, so it is quite confusing because

According to the torque data obtained from CFD Analysis tool, turbine power is obtained as in Table 10 and efficiencies data as in Table 11. Based on Table 11, the highest efficiency was obtained by the turbine with twisted-3 blade- $490 \mathrm{~mm}$ configuration at flow velocity $5.490 \mathrm{~m} / \mathrm{s}$ and turbine with twisted-3 blade- $650 \mathrm{~mm}$ configuration at flow velocity $2.745 \mathrm{~m} / \mathrm{s}$ and $4.118 \mathrm{~m} / \mathrm{s}$.

Based on Figure 8(b), turbines with twisted blade shapes have several turbines with higher efficiency. In theory, the blade is in the twisted shape to reduce drag force (attraction), so that more energy can be converted into power. But on the other hand, the shape of the twisted aims to get the optimal angle of attack at the tip of the blade (tip). However, efficiency tends to be lower in the form of a blade with a twisted shape, this is probably due to the simulation results that are less accurate due to lowquality meshing.

Based on Figure 9(a), it is known that turbines with a low number of blades have higher efficiency. This is in $P_{\text {out }}$ vs Water Velocity

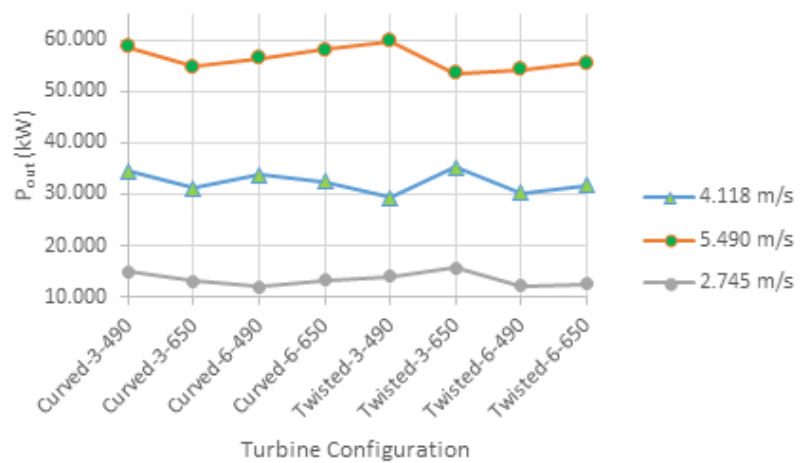

Figure 8(b). Power of Turbine vs Water Velocity Efficiency vs Water Velocity

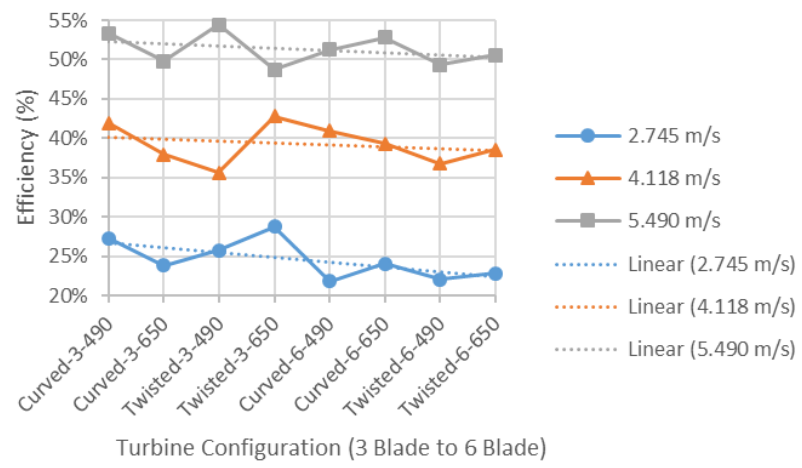

Figure 9(b). Efficiency vs Water Velocity

(Comparison Between 3 Blade and 6 Blade)

accordance with the theory which says when the number of blades increases, it will increase the resistance in the water flow, the torque will increase and the RPM will decrease. So, the number of blades is inversely proportional to turbine efficiency.

Based on Figure 9(b), it is known that turbines with shorter chords tend to have higher efficiency, while longer chords tend to have lower efficiency. So, the chord length is inversely proportional to turbine efficiency. The lower length of the chord has high efficiency, probably due to its lighter weight, so that it can absorb greater thrust with smaller losses.

\section{CONCLUSION}

The turbine efficiency is directly proportional to the flow velocity. This can be seen from each turbine configurations, their efficiency increases every time the river speed gets higher. The highest efficiency turbine is T-3-490 configuration with an efficiency of $25.71 \%$, $35.58 \%, 54.40 \%$ at each speed. The variation in river speed analyzed is $2.745 \mathrm{~m} / \mathrm{s}, 4.118 \mathrm{~m} / \mathrm{s}, 5.490 \mathrm{~m} / \mathrm{s}$.

The efficiency of the turbine is inversely proportional to the number of blades. Turbines with 3 blades tend to have higher efficiency than turbines with 6 blades. Where the highest efficiency with 3 blades is T-3-490 turbine at $54.40 \%$ at the highest flow speed, while the highest efficiency with 6 blade turbine is C-6-650 at 52.84\% at the highest flow rate.

Turbine efficiency is inversely proportional to the length of the chord. Turbines with $490 \mathrm{~mm}$ chord length 
tend to have higher efficiency than turbines with $650 \mathrm{~mm}$ chord length. Where the highest efficiency with $490 \mathrm{~mm}$ chord length is T-3-490 turbine at $54.40 \%$ at the highest flow speed, when the chord length is $650 \mathrm{~mm}$, the highest efficiency turbine is C-6-650 at 52.84\% at the highest flow speed.

The efficiency of the turbine is greater when the turbine blade is twisted. Turbines with curved shaped blades tend to have higher efficiency than turbines with twisted shaped blades. Nevertheless, the blade with the twisted shape has the highest efficiency, where the highest efficiency of a twisted blade is the T-3-490 turbine at $54.40 \%$ at the highest flow speed, while the highest efficiency in the curved blade is C-3-490 at $53.31 \%$ at the highest flow speed.

\section{REFERENCES}

[1] E. L. C. Arrieta, S. A. Flórez and N. I. Sierra, "Application of CFD to the design of the runner of a propeller turbine for small hydroelectric power plants," SciELO, vol. 69, 2013.

[2] R. Dhakal, "Computational and experimental investigation of runner for gravitational water vortex power plant," 2017 IEEE 6th International Conference on Renewable Energy Research and Applications (ICRERA), vol. 373, p. 363, 2017.

[3] Turbulent, "Vortex Turbine," Turbulent, 2018. [Online]. Available: https://www.turbulent.be/technology/. [Accessed 10 Agustus 2018].

[4] NASA, "Global Climate Change," 2018. [Online]. Available: https://climate.nasa.gov/. [Accessed 10 Agustus 2018].

[5] M. Hutapea, Solusi Listrik Off-Grid Berbasis Energi Terbarukan di Indonesia: Kerangka Regulasi dan Program, Jakarta: Direktorat Jenderal Energi Baru Terbarukan dan Konservasi Energi, 2016.

[6] O. B. Yaakoba, Y. M. Ahmed, A. H. Elbatran and H. M. Shabara, "A Review on Micro Hydro Gravitational Vortex Power and Turbine Systems," Jurnal Teknologi (Sciences \& Engineering), vol. 69, pp. 1-7, 2014.

[7] A. Mohanan, "Power Generation with Simultaneous Aeration using a Gravity Vortex Turbine," International Journal of Scientific \& Engineering Research, vol. 7, no. 2, pp. 19-24, 2016.

[8] M. M. Rahman, J. H. Tan, M. T. Fadzlita and A. R. W. K. Muzammil, "A Review on the Development of Gravitational Water Vortex Power Plant as Alternative Renewable Energy
Resources," International Conference on Materials Technology and Energy, vol. 217, 2017.

[9] C. Power, A. McNabola and P. Coughl, "A Parametric Experimental Investigation of the Operating Conditions of Gravitational Vortex Hydropower (GVHP)," Journal of Clean Energy Technologies, vol. 4, no. 2, pp. 112-119, 2016.

[10] R. M. Lopulalan, S. Sarwito and E. S. Koenhardono, "Desain Blade Turbin Pembangkit Listrik Tenaga Arus Laut di Banyuwangi Berbasis CFD," JURNAL TEKNIK ITS, vol. 5, pp. B424-B430, 2016.

[11] C. Penche, Guide on How to Develop a Small Hydropower Plant, Belgium: ESHA, 2004.

[12] S. Mulligan, Experimental and Numerical Analysis of ThreeDimensional Free-Surface Turbulent Vortex Flows with Strong Circulation, Ireland: Institute of Technology Sligo, 2015.

[13] A. Santoso, I. S. Arief, and A. T. Kurniawan, "Performance Analysis Rim Driven Propeller as a Propulsor using Open Water Test," International Journal of Marine Engineering Innovation and Research, vol. 2, no. 1, pp. 70-76, 2017.

[14] R. Pietersz, R. Soenoko and S. Wahyudi, "Pengaruh Jumlah Sudu Terhadap Optimalisasi Kinerja Turbin Kinetik Roda Tunggal," Jurnal Rekayasa Mesin, vol. 4, no. 3, pp. 220-226, 2013.

[15] M. M. Gheorghe, S. Tudor and A. Abdelkrim, "Study of Micro Hydropower Plant Operating in Gravitational Vortex Flow Mode," Applied Mechanics and Materials, vol. 371, pp. 601-605, 2013.

[16] Y. Nishi and T. Inagaki, "Performance and Flow Field of a Gravitation Vortex Type Water Turbine," International Journal of Rotating Machinery, vol. 2017, pp. 1-11, 2017.

[17] M. Rahman, T. J. Hong, R. Tang, L. L. Sung and F. B. M. Tamiri, "Experimental Study the Effects of Water Pressure and Turbine Blade Lengths \& Numbers on the Model Free Vortex Power Generation System," International Journal of Current Trends in Engineering \& Research (IJCTER), vol. 2, no. 9, pp. 13-17, 2016

[18] T. F. Nugroho, E. M. Wardhana and R. N. Azmi, "Stress Analysis of Land Subsidence Effect on Header Pipe 12 Inch in LPG Station Semarang," International Journal of Marine Engineering Innovation and Research, vol. 2, no. 4, pp. 261-268, 2018.

[19] A. Santoso and B. Ilmi, "Analysis of Erosion Rate on Discharge Slurry HDPE Pipe in Canal Water Intake PLTGU Grati using CFD Simulation," International Journal of Marine Engineering Innovation and Research, vol. 2, no. 4, pp. 253-260, 2018.

[20] H. Prastowo, A. Santoso and A. Arya, "Analysis and Optimation Hydrofoil Supported Catamaran (HYSUCAT) Size 25 Meter Based on CFD Method," International Journal of Marine Engineering Innovation and Research, vol. 1, no. 1, pp. 31-37, 2016 